\title{
Improvement in CBR value of soil reinforced with nonwoven geotextile sheets
}

\author{
S. Ramjiram Thakur ${ }^{1}$, B. P. Naveen ${ }^{2^{*}}$ (1) and J. P. Tegar $^{3}$
}

\author{
*Correspondence: \\ bpnaveen@ggn.amity.edu \\ ${ }^{2}$ Department of Civil \\ Engineering, Amity \\ University, Manesar 122413, \\ Gurgaon, India \\ Full list of author information \\ is available at the end of the \\ article
}

\begin{abstract}
Geosynthetics are human made material used to reinforce soils to improve the bearing capacity and permeability of the soil, reducing soil settlement. Geosynthetics application plays a vital role in the highways constructions with no additive layers, such as cement concrete, asphalt concrete, or in a subgrade layer that affects the bearing capacity of unbounded layers. This paper presents the geosynthetics as a tensional material that has been used for reinforcement of clayey soil. Laboratory California bearing ratio (CBR) test samples were prepared with clayey soils. Clayey soil containing unreinforced soil and reinforced soil. The sample comprised thermally bonded nonwoven geotextiles (NW) and superior needle-punched nonwoven geotextiles (SNW) with different characteristics (NW 8, 10, 21, 30 and SNW 14, 25, 62, 75) with three-layered, based on the sample materials to perform defined tests. These tests show that, bearing ratio of reinforced soils with thermally bonded nonwoven geotextiles increases.
\end{abstract}

Keywords: Geosynthetics, Geotextiles, California bearing ratio, Reinforced soil

\section{Introduction}

In ancient times, significant developments in structural engineering have only been possible because of parallel developments in construction materials' technology. An immense and further elaborate structure became possible as it went from using wood to building stone to concrete to reinforced concrete and recently to prestressed reinforced concrete. The steel development accredits the longer span bridges construction and taller buildings than were possible using wrought iron. However, geotechnical materials are soil and rock; it is hard to expect similar parallel developments in geotechnical constructions. Ground improvement techniques for soil improvement occurred mainly because of actions in construction equipment by manufacturers and contractors. In direct relation with reinforced concrete, steel, and polymer materials, impart tensile resistance, and soils' stability but have low to no tensile strength [1].

Polymeric reinforcement materials are the recent developments in civil engineering materials: geosynthetics. Geosynthetics are planar products manufactured from the synthetic (polymeric material) used in various fields such as geotechnical, landfill, transportation, and hydraulics. Geosynthetic with higher tensile strength is used as a reinforcement material in soils to improve the performance of civil engineering applications. Geosynthetic material acting as reinforcement and resisting

(c) The Author(s) 2021. This article is licensed under a Creative Commons Attribution 4.0 International License, which permits use, sharing adaptation, distribution and reproduction in any medium or format, as long as you give appropriate credit to the original author(s) and the source, provide a link to the Creative Commons licence, and indicate if changes were made. The images or other third party material in this article are included in the article's Creative Commons licence, unless indicated otherwise in a credit line to the material. If material is not included in the article's Creative Commons licence and your intended use is not permitted by statutory regulation or exceeds the permitted use, you will need to obtain permission directly from the copyright holder. To view a copy of this licence, visit http://creativeco mmons.org/licenses/by/4.0/. 
applied stresses or preventing unacceptable deformations in reinforced geotechnical structures. In this process, geosynthetic fabric serves as a tensioned member of the composite material. It restrains tensile deformations by mobilizing tensile load in geosynthetic and resists the soil from sliding by providing bond resistance, adhesion, interlocking, or confinement and thus maintains the stability of the soil mass [2].

In recent decades, high volume traffic pavements transfer their traffic load on asphalt or concrete treated surface over a base course layer and distribute the traffic load on the subgrade. When the subgrade soil is soft or not capable of withstanding adequate traffic loads for an extended period due to environmental pressures or either traffic, it results in deformation in the pavement [3]. In such situations, geosynthetics can be utilized to improve the performance of the unpaved road by increasing the lifetime and minimizing the maintenance cost and reducing the thickness of the road.

Geosynthetics with high tensile strength used in soft soil are useful in designing several civil engineering projects. The use of reinforcements will provide additional shear stress in the soil mass through the tensile force in the reinforcement, which will increase the strength of soil-reinforcement mass, and hence reduce the horizontal deformations, and thereby increasing the overall stability of the soil structure such as roads, retaining walls, embankment, and slope.

The primary usage of unpaved roads is economical for low traffic volume and access to highways [4]. Generally, in a developing country, the rural roads connecting agricultural villages are main in improving the rural economy. When these types of roads with soft soil are built, there will be a possibility for massive deformation to happen, which triggers the maintain cost and results in interruption of traffic service [5]. Applications of geosynthetics as a reinforcement to improve soft soil is currently a popular method. The high tensile strength of geosynthetics and soil interaction plays a significant role in improving the soil. With varying fine content within the sand can alter the interface behavior between soil and geosynthetics. Shrinking and swelling movement is the result of the irregular road surface and road deterioration. In such situations, geosynthetics can be used to improve the performance of unpaved roads by increasing the lifetime; these results in minimizing the maintenance cost as well as reducing the thickness of unpaved roads [6].

Several design concepts for paved and unpaved roads based on CBR value are available in the literature. Many researchers have studied substantial experimental and analytical research work relating to geosynthetic interfaced soil/aggregate (e.g., [7-10]).

Large-scale laboratory tests and full-scale Insitu tests $[5,11,12]$ are carried out to determine unpaved roads' performance. CBR tests are conducted by introducing geotextiles and geogrid in granular soil [13]. Further, geotextile, geogrid, and geonet's influence by using the CBR test are investigated in cohesive soil with low compressibility $[14,15]$ as soft subgrade in unpaved roads. Therefore, in this study, the effect thermally bonded nonwoven geotextiles (NW) and superior needle-punched nonwoven geotextiles (SNW) on clayey soil's CBR strength is carried out considering the clay with high compressibility as the soft subgrade. 


\section{Experimental studies}

Locally available soil on the campus of NITTTR Bhopal has been used as subgrade material in the experiments. The soil used is classified as $\mathrm{CH}$ (Clay of high plasticity). The various index properties and compaction properties of soil were evaluated in the laboratory, which is given in Table 1. The geosynthetics used in the experiments are thermally bonded nonwoven geotextile's $(\mathrm{NW})$ and superior needle-punched nonwoven geotextile's (SNW) geotextile's. The photographs of the NW and SNW materials used in the CBR tests are shown in Figs. 1 and 2. A thermally bonded nonwoven geotextile's (NW) and superior needle-punched nonwoven geotextile's (SNW) geotextile's properties by the GEO NATPET manufacturers are given in Tables 2 and 3.

\section{Sample preparation}

All the experiments were performed as per the standard procedure established by the American Society for Testing and Materials (ASTM 2006). In the present study, California bearing ratio (CBR) was used for the tests. These tests were conducted based on ASTM D 1883. Also, compaction test was performed on material according to ASTM D 698. The experimental studies involved a series of CBR tests that were carried out on reinforced soil systems. For preparing reinforced soil systems, the reinforcement viz., thermally bonded nonwoven geotextiles, and superior

Table 1 Properties of the clay

\begin{tabular}{ll}
\hline Particulars & Soil \\
\hline Colour & Red \\
Specific gravity (G) & 2.71 \\
Soil classification & $\mathrm{CH}$ \\
Liquid limit (LL) and Plastic limit (PL),\% & 58 and 25 \\
Plasticity Index (PI), \% & 33 \\
Optimum moisture content (OMC), \% & 16 \\
Maximum dry density (MDD), $\mathrm{Yb}_{\mathrm{b}}\left(\mathrm{g} / \mathrm{cm}^{3}\right)$ & 1.51 \\
\hline
\end{tabular}
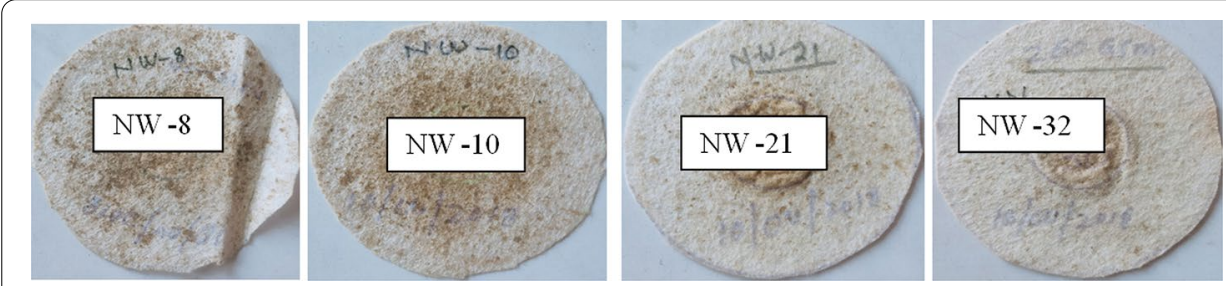

Fig. 1 Thermally bonded nonwoven geotextiles

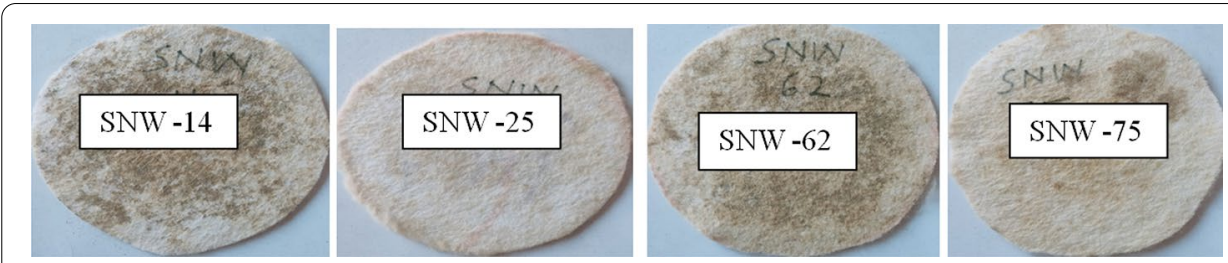

Fig. 2 Superior needle-punched nonwoven geotextiles 
Table 2 Properties of thermally bonded nonwoven geotextiles (NW series)

\begin{tabular}{lllll}
\hline Properties & NW 8 & NW 10 & NW 21 & NW 32 \\
\hline Tensile strength, kN/m & 8 & 10 & 21 & 32 \\
Elongation at break, \% & $40-45$ & $40-45$ & $50-55$ & $50-60$ \\
CBR, puncture resistance, $N$ & 1200 & 1600 & 3500 & 5400 \\
Dynamic cone drop, mm & 34 & 28 & 15 & 10 \\
Thickness, $\mathrm{mm}$ & 1.00 & 1.15 & 1.85 & 2.30 \\
Weight, $\mathrm{g} / \mathrm{m}^{2}$ & 100 & 120 & 260 & 385 \\
\hline
\end{tabular}

Table 3 Properties of superior needle-punched nonwoven geotextiles (SNW series)

\begin{tabular}{llllr}
\hline Mechanical properties & SNW 14 & SNW 25 & SNW 62 & SNW 75 \\
\hline Tensile strength, kN/m & 8 & 14 & 37 & 43 \\
Elongation at break-MD, \% & 40 & 45 & 60 & 60 \\
CBR, puncture resistance, N & 1400 & 2500 & 6200 & 7400 \\
Dynamic cone drop, mm & 28 & 18 & 5 & 4 \\
Thickness, mm & 1.2 & 1.8 & 3.5 & 4 \\
Weight, $\mathrm{g} / \mathrm{m}^{2}$ & 120 & 200 & 500 & 600 \\
\hline
\end{tabular}

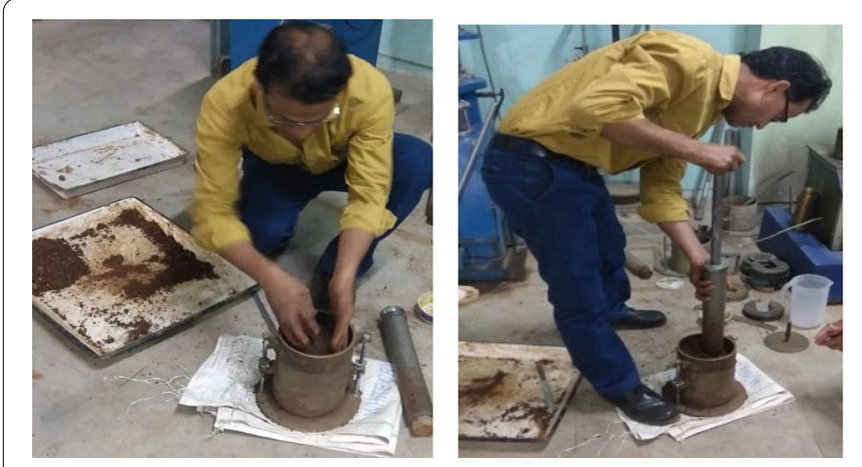

Fig. 3 Preparation of the reinforced soil sample for CBR test

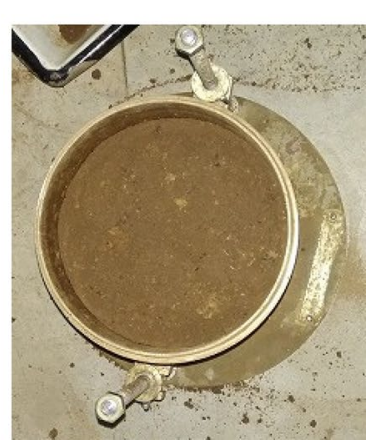

needle-punched nonwoven geotextiles were placed at the soil layers' interface. To understand the effect of mould size on the load-penetration response of reinforced soil systems, experiments were carried out in the conventional CBR mould of $150 \mathrm{~mm}$ diameter. The height of the mould used in the tests is $175 \mathrm{~mm}$, and that of the collar is $50 \mathrm{~mm}$. A total of eight experiments were carried out in the mould. The soil used in the tests was filled in the mould of $175 \mathrm{~mm}$ height in 3 equal lifts at standard proctor density (Fig. 3). To understand the beneficial effect of reinforcement while conducting CBR tests on reinforced soil systems, the geotextiles viz., thermally bonded nonwoven geotextiles or superior needle-punched nonwoven geotextiles were placed at the middle of the soil sample and two geotextile layers in distances of one third in the soil sample. The schematic sketch of the reinforced soil system prepared in the mould of $150 \mathrm{~mm}$ diameter is shown in Fig. 4. The schematic test setup of the CBR test is shown in Fig. 5. 


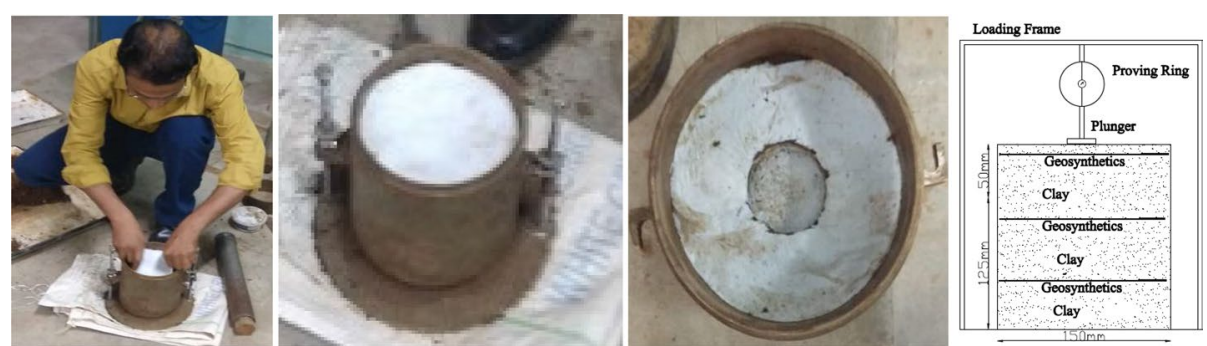

Fig. 4 Position of the geotextiles in CBR mould

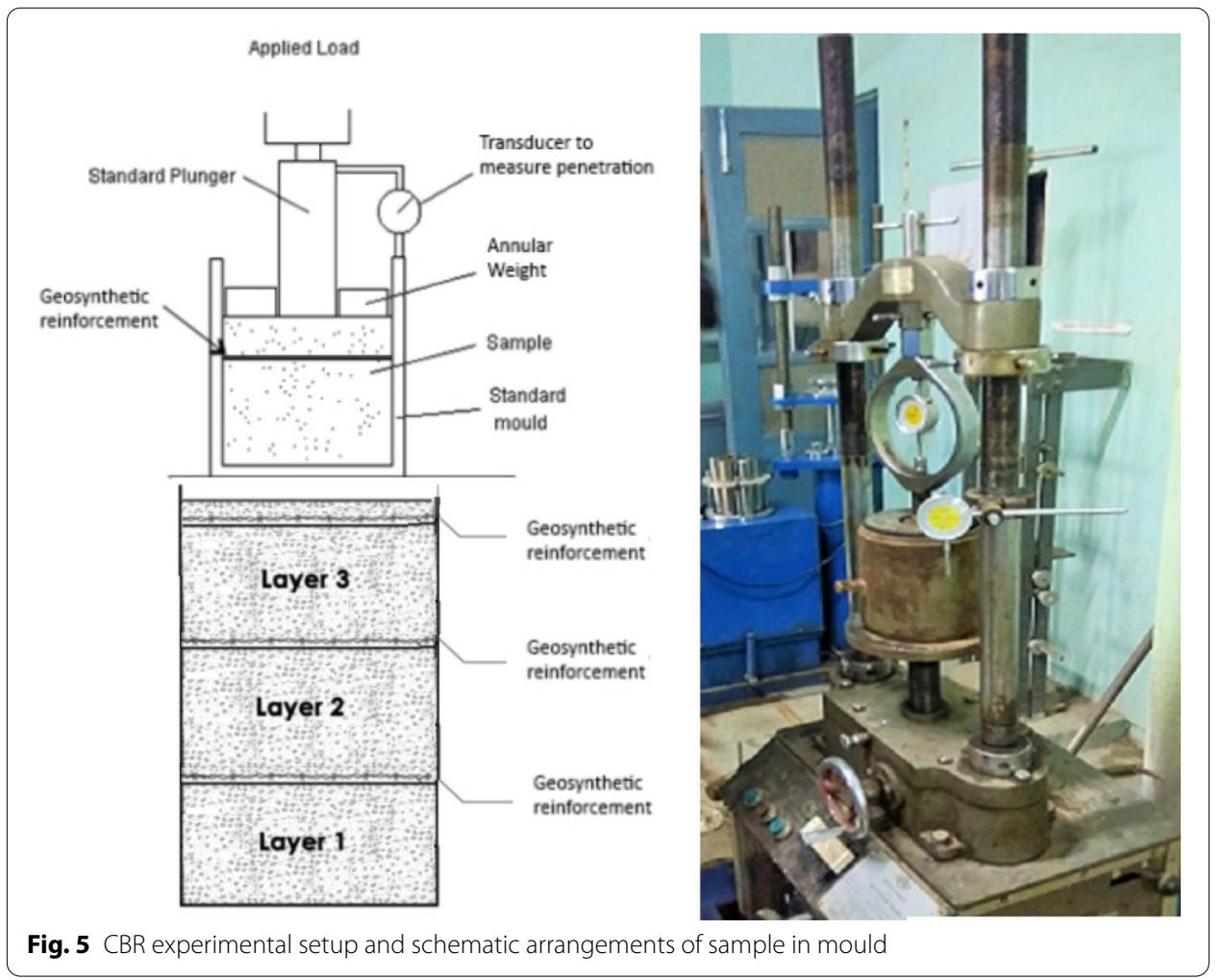

\section{Results and discussion}

In the present study, clayey soil and two types of thermally bonded nonwoven geotextiles (NW) and superior needle-punched nonwoven geotextiles (SNW) are used for the study. CBR tests are carried out on unreinforced soil specimens with and without geotextiles. Figure 6 illustrates the load-penetration response of the NW soil. The CBR value of soil increases with the inclusion of NW. When the NW thickness is increases, the CBR value of soil is further increases and this increase is substantial at NW-30. It was also found that preparation of identical soil samples for CBR test beyond NW-21 of geotextile's is not feasible and optimum geotextile's content was found to be NW-21.

Similarly, the CBR value of soil increase with the inclusion of SNW (Fig. 7). When the SNW thickness is increases, the CBR value of soil is further increases slightly and optimum geotextile's content was found to be SNW-62. Beside, SNW geotextile's is made up 


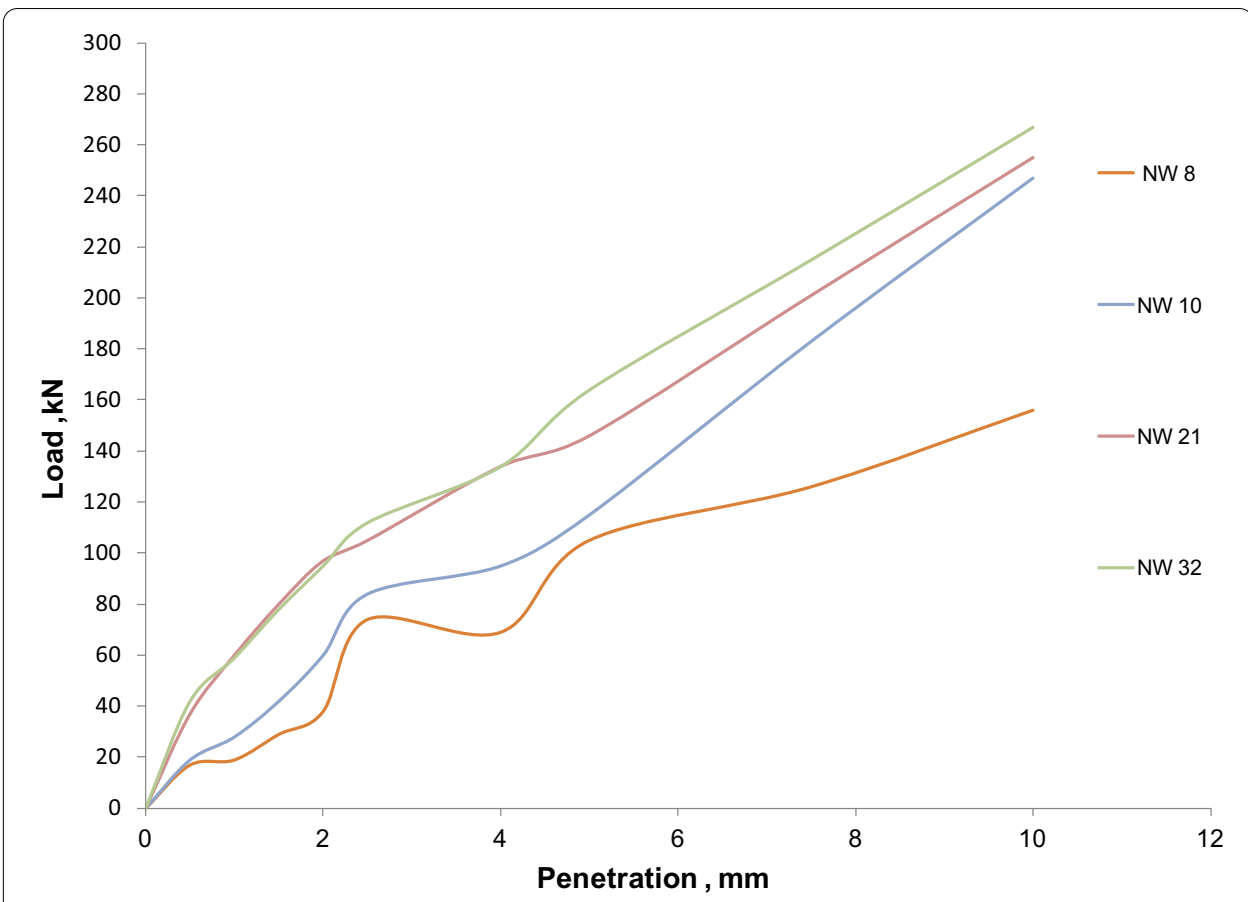

Fig. 6 Load-penetration response of the NW Soil

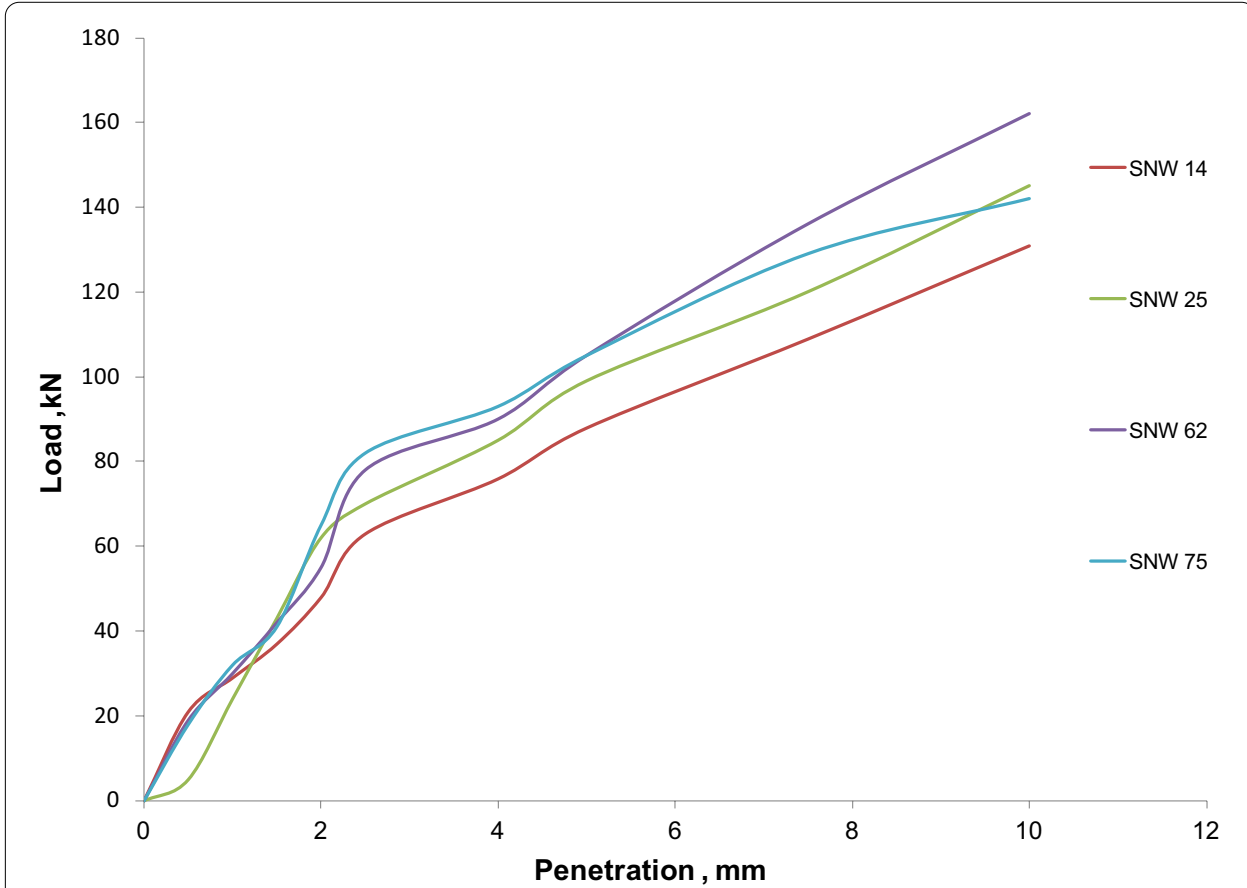

Fig. 7 Load-penetration response of the SNW soil

of tangled threads of $100 \%$ polypropylene, which give it superior strength to stand up to the stress of construction and installation. SNW geotextile's resistant to UV and natural degradation, providing a long lasting economical product. 
From Fig. 8, it is clear confirms the strength mobilization principle of the NW and SNW geotextile's materials in general, which emphasized that the strong mobilization of reinforcing geotextile's material very much depends on the range of CBR of soil sample. The NW geotextile's owed to their high tensile strength were effective in strengthening the soil and the performance of both these reinforcements are in par with each other. However, NW geotextile's performance was found to be in par with that of SNW and unreinforced soil. Also, SNW geotextile's acts a separator to prevent the intermixing of the different soil layer types, and as filter to allow the flow of fluids while preventing the passage of soil particles. SNW geotextile's offer a cost effective alternative for separation, filtration and protection applications. Therefore, NW and SNW geotextile's are practical tools in the civil engineer's hands that have proved to solve any types of geotechnical problems.

The following observation (Table 4) using NW and SNW in soil by three layers confirms the geotextile strength mobilization principle in general, which emphasized that the strong mobilization of reinforcing geotextile material very much depends on the range of CBR of soil sample. The NW soil sample CBR the more effective the strength mobilization effects of geotextile material in general. When the NW thickness is increases, the CBR value of soil is further increases and this increase is substantial at NW-30. This may be due to the fact that reinforcing elements interact with soil particles mechanically through surface friction and by interlocking. The function of the bond is to transfer the stress from the soil to the reinforcing elements by mobilizing the tensile strength of reinforcing elements which results into decrease in tensile strain and improvement in load carrying capacity of reinforced soil. Therefore, it can be concluded that addition of NW and SNW geotextile's sheet in soil improves its load carrying

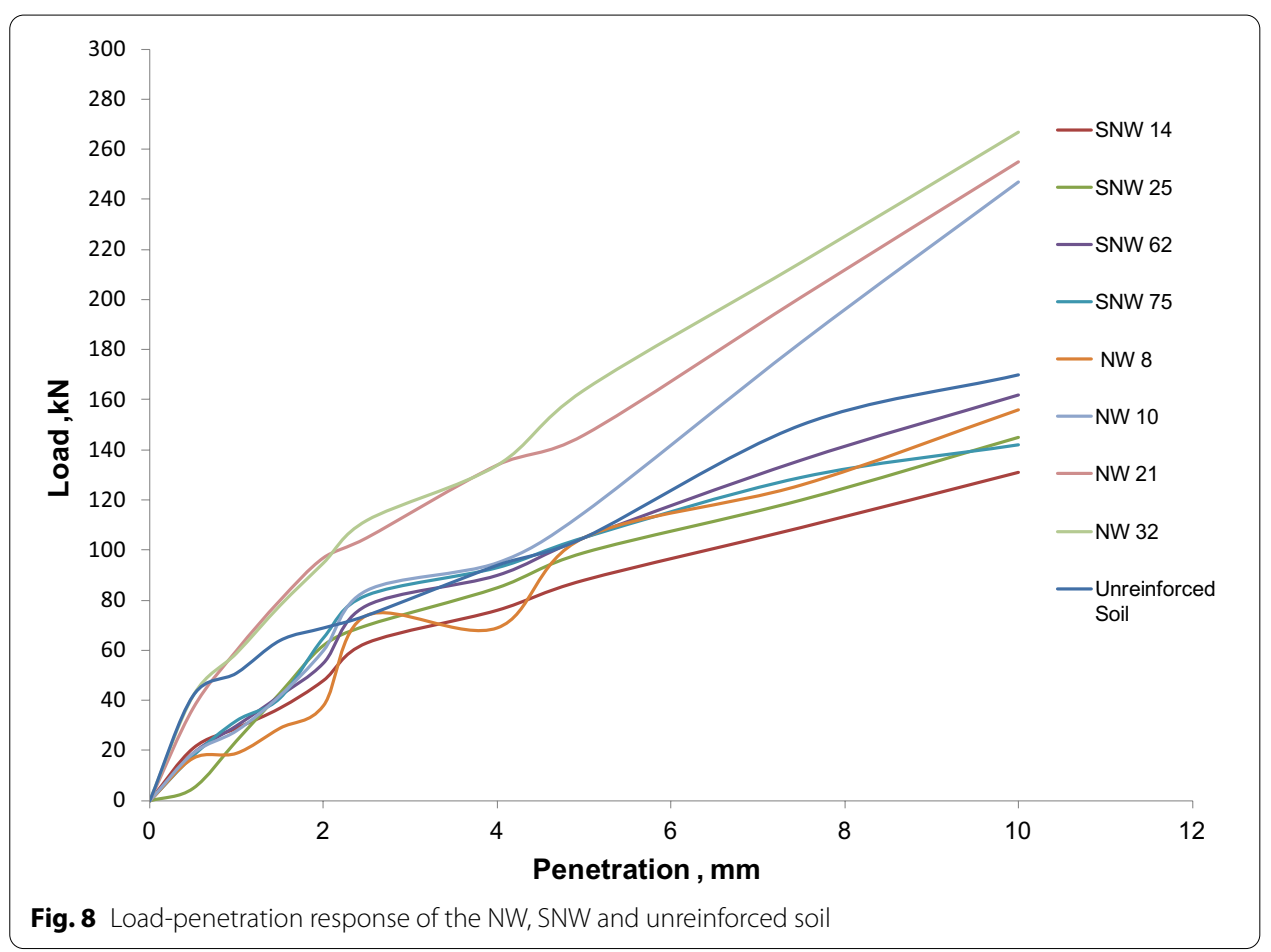


Table 4 Comparison of various geotextile's with unreinforced soil

\begin{tabular}{lll}
\hline Parameters & $\begin{array}{l}\text { For } \mathbf{2 . 5} \mathbf{~ m m ,} \\
\text { CBR, \% }\end{array}$ & $\begin{array}{l}\text { For } \mathbf{5 ~ m m}, \\
\text { CBR, \% }\end{array}$ \\
\hline SNW 14 & 16 & 15.7 \\
SNW 25 & 18.2 & 16.1 \\
SNW 62 & 20 & 17 \\
SNW 75 & 21 & 18 \\
NW 8 & 19 & 18 \\
NW 10 & 21.5 & 19.7 \\
NW 21 & 27 & 25 \\
NW 30 & 29 & 28 \\
Unreinforced soil & 19 & 18 \\
\hline
\end{tabular}

capacity and reduce the value of immediate settlement. With the availability of a variety of products with different characteristics, the design engineer needs to be aware of the application possibilities and, more specifically, why he is using the geotextile and the governing geotextile functional properties to satisfy these functions. The design and selection of SNW and NW geotextiles based on sound engineering principles will serve both the user and the industry's long-term interest. Meantime, SNW geotextile's are a thick filter that offers outstanding performance at minimum weight. Compared to other needle-punched geotextile's of similar weight, SNW provides superior puncture resistance and is ideal for liner protection, basal geomembrane protection, and coastal protection applications. Similarly, NW geotextiles are non-woven, needle punched, heat-treated fabrics designed to offer optimum performance per with high mechanical and hydraulic properties making them the ideal choice for separation and filtration applications. This result has been able to show the beneficial functions of thermally bonded nonwoven geotextiles or superior needle-punched nonwoven geotextiles in various earthen structures in various applications.

\section{Ultimate bearing capacity}

The CBR tests were performed by ASTM D 1883. The penetration resistance load is then plotted against the penetration depth, and correction is applied for the load penetration curve. Using corrected value taken from the load penetration curve for $2.54 \mathrm{~mm}$ and $5.08 \mathrm{~mm}$ penetration, the bearing ratio is estimated by dividing the corrected load by the corresponding standard load, multiplied by 100 .

Black [16] developed a correlation between the ultimate bearing capacity $\left(\mathrm{q}_{\mathrm{u}}\right)$ and the CBR of cohesive soil. Black recommended that the developed correlation depends on soil types and method of compaction. The computed values of ultimate bearing capacity $\left(q_{u}\right)$ and unsoaked CBR for the studied soils are presented in Table 5. Black [16] equation estimates significantly the ultimate bearing capacity especially for the higher CBR values. The improvement in bearing capacity of soil due to the introduction of NW and SNW geotextile's materials. The study indicated that the NW geotextile's layer between the soil sub-bases could increase the soft soil subgrade's bearing capacity. Also, results indicated that the NW geotextile's layer increases the load capacity of the pavement layers. Similarly Sharma et al. [17] proved that the soil bearing capacity improved when 
Table 5 Summary of tests results for geotextile's with unreinforced soil

\begin{tabular}{llc}
\hline Parameters & Unsoaked CBR, \% & qu, (kPa) \\
\hline Unreinforced soil & 19 & 13.3 \\
SNW 14 & 16 & 11.2 \\
SNW 25 & 18.2 & 12.7 \\
SNW 62 & 20 & 14.0 \\
SNW 75 & 21 & 14.7 \\
NW 8 & 19 & 13.3 \\
NW 10 & 21.5 & 15.1 \\
NW 21 & 27 & 18.9 \\
NW 30 & 29 & 20.3 \\
\hline
\end{tabular}

reinforced by geotextile's and that better improvements were obtained when the reinforcement is placed with a influence depth beyond which no significant improvement will occur.

\section{Conclusions}

California bearing ratio (CBR) tests were carried out in the laboratory and the following conclusions were arrived at,

1. The inclusion of NW geotextiles materials in soils improves the CBR and therefore the strength of soils. It implies that geotextile's-reinforced soils in various earthen structures will perform better than unreinforced ones and increase load carrying capacity of soils.

2. Black [16] equation estimates significantly the ultimate bearing capacity especially for the higher CBR values.

3. Based on the present study it is concluded that the load carrying capacity of soil increases and amount of immediate settlement decreases when soil is reinforced with NW and SNW geotextile's sheets.

4. SNW geotextile's offer a cost effective alternative for separation, filtration and protection applications.

Authors' contribution

Naveen \& Tegar, organized the field and laboratory studies and Naveen wrote the paper. Ramjiram performed field and laboratory studies. All authors read and approved the final manuscript.

Author details

${ }^{1}$ Department of Civil Engineering, NRI Group of Institutions Bhopal, Bhopal 462023, Madhya Pradesh, India. ${ }^{2}$ Department of Civil Engineering, Amity University, Manesar 122413, Gurgaon, India. ${ }^{3}$ Department of Civil and Environmental Engineering, National Institute of Technical Teachers'Training and Research Bhopal, Bhopal 462002, Madhya Pradesh, India.

Received: 1 August 2020 Accepted: 15 December 2020

Published online: 09 March 2021 
References

1. Holtz RD (2001) Geosynthetics for soil reinforcement. The Ninth Spencer J. Buchana Lecture, College Station Hilton, TX, pp 1-19

2. Awdhesh KC, Murali Krishna A (2011) Soil-geosythetics interaction properties for different types of soil. In: Proceedings of India geotechnical conference, December 15-17, Kochi, pp 585-588

3. Al Qurishee M (2017) Application of geosynthetics in pavement design. Int Res J Eng Technol 4(7):1-7

4. Salih K, Shabana AC, Shamseera P, Shyamili TM, Sruthi V (2014) Study on CBR values of soil with crushed coconut shells. Int J Adv Eng Technol 5(3):55-58

5. Subaida EA, Chandrakaran S, Sankar N (2009) Laboratory performance of unpaved roads reinforced with woven coir geotextils. Geotext Geomembr 27:204-210

6. Deb K, Konai S (2014) Bearing capacity of geotextile-reinforced sand with varying fine fraction. Geomech Eng 6(1):33-45

7. Basu G, Roy AN, Bhattacharyya SK, Ghosh SK (2009) Construction of unpaved rural road using jute-synthetic blended woven geotextile-a case study. Geotext Geomembr 27:506-512

8. Giroud JP, Noiray L (1981) Geotextile-reinforced unpaved road design. J Geotech Div ASCE 107:1233-1254

9. Giroud JP, Ah-Line C, Bonaparte R (1985) Design of unpaved road and trafficked areas with Geogrids. In: Proceedings of conference on Polymer Grid Reinforcement, Thomas Telford Limited, London, pp 116-127

10. Hu YC, Zhang YM (2007) Analysis of load-settlement relationship for unpaved road reinforced with Geogrid. First international symposium on geotechnical safety and risk, Tongji University, Shanghai, China, pp 609-615

11. Bergao DT, Youwai S, Hai CN, Voottipruex P (2001) Interaction of nonwoven needle-punched geotextiles under axisymmetric loading conditions. Geotext Geomembr 19:299-328

12. Elvidge CB, Raymond GP (1999) Laboratory survivability of nonwoven geotextiles on open-graded crushed aggregate. Geosynth Int 6(2):93-117

13. Dhule SB, Valunjkar SS, Sarkate SD, Korrane SS (2011) Improvement of flexible pavement with use of geogrid. Electron J Geotech Eng 16(Bundle C):269-279

14. Moayed RZ, Nazari M (2011) Effect of utilization of geosynthetic on reducing the required thickness of subbase layer of a two layered soil. World Acad Sci Eng Technol. 49(175):963-967

15. Srivastava RK, Jalota AV, Singh R (1995) Model studies on geotextile reinforced pavements. Indian Highw 23(9):31-39

16. Black WPM (1962) A method of estimating the California bearing ratio of cohesive soils from plasticity data. Geotechnique 12:271-282

17. Sharma R, Chen Q, Abu-Farsakh M, Yoon S (2009) Analytical modeling of geogrid reinforced soil foundation. Geotext Geomembr 27:63-72

\section{Publisher's note}

Springer Nature remains neutral with regard to jurisdictional claims in published maps and institutional affiliations.

\section{Submit your manuscript to a SpringerOpen ${ }^{\circ}$ journal and benefit from:}

Convenient online submission

- Rigorous peer review

- Open access: articles freely available online

- High visibility within the field

Retaining the copyright to your article

Submit your next manuscript at $\boldsymbol{\Delta}$ springeropen.com 